Article

\title{
Synthesis of Two New Hemisynthetic Diterpenylhydroquinones from Natural Ent-Labdanes
}

\author{
Luis Espinoza Catalán ${ }^{1}$,*, Karen Catalán Marín ${ }^{1}$, Alejandro Madrid Villegas ${ }^{1}$, Héctor \\ Carrasco Altamirano ${ }^{2}$, Joan Villena García ${ }^{3}$ and Mauricio Cuellar Fritis ${ }^{4}$
}

1 Departamento de Química, Universidad Técnica Federico Santa María, Av. España $N^{\circ} 1680$, Valparaíso, Chile

2 Departamento de Ciencias Químicas, Universidad Andrés Bello, Campus Viña del Mar, Los Fresnos $\mathrm{N}^{\circ}$ 52, Viña del Mar, Chile

3 Facultad de Medicina, Universidad de Valparaíso, Centro Regional de Estudios en Alimentos Saludables, Creas, Av. Hontaneda N 2664, Valparaíso, Chile

4 Facultad de Farmacia, Universidad de Valparaíso, Av. Gran Bretaña No 1093, Valparaíso, Chile

* Author to whom correspondence should be addressed; E-mail: luis.espinozac@usm.cl

Received: 10 May 2009; in revised form: 26 May 2009 / Accepted: 2 June 2009 /

Published: 17 June 2009

\begin{abstract}
The synthesis and structural determination of two new diterpenylhydroquinones:

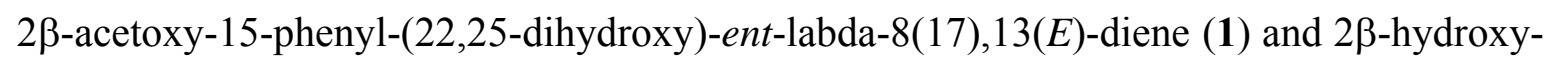
15-phenyl-(22,25-dihydroxy)-ent-labda-8(17),13(E)-diene is reported (2). These compounds were obtained by coupling via Electrophilic Aromatic Substitution (EAS) of 1,4-hydroquinone with primary or tertiary allyl alcohol derivatives of the natural entlabdanes 3 and 4 . With this new method, the best results were observed when mixtures of the primary alcohol derivatives 5-6 (26\% yield of compound 1) and diol derivatives 9-10 ( $28 \%$ yield of compound 2 ) were used.
\end{abstract}

Keywords: diterpenyl-hydroquinones; synthesis; ent-labdanes; NMR structural determination 


\section{Introduction}

Terpenylquinones and terpenylhydroquinones are characteristic marine metabolites with examples of 4,9-friedodrimane, drimane and nordrimane skeletons, frequently isolated from alga and/or sponge genera [1]. This class of compounds has attracted the attention of researchers because to their potent biological properties, which include antimicrobial [2], antileukemic [3], cytotoxic [4-6], hemolytic [7], and immunomodulatory activities [8-9]. In the late 1980s, there was significant interest in the possible anti-HIV activity of marine sesquiterpenes [1,10-12]. These compounds are generally characterized as having a bicyclic sesquiterpene skeleton attached to a (hydro)quinone moiety in its structures.

The more recurrent synthetic strategies used for synthesizing terpenylquinones/hydroquinones, involve, as a first step, the separate preparation of the appropriate terpenyl and aromatic nucleus fragments. The crucial step is the attachment of the aromatic synthon to the terpenyl skeleton and the final step is the formation of oxygenated functions (generally by oxidation of hydroxyl or methoxyl groups) on the quinone moiety. The more used methods for the coupling reactions are the following: 1) Nucleophilic addition of aryllithium derivatives to carbonyls of the terpenyl unit (synthesis of $(+)$ puupehenone [13]); 2) Diels-Alder and hetero Diels-Alder cycloaddition (synthesis of (-)cyclozonarone [14] and (+)-cyclozonarone [15]); 3) Enolate alkylation with benzyl bromide derivatives (synthesis of (-)-ilimaquinone [16]); 4; Conjugated 1,4-addition; Michael addition (synthesis of (-)-yahazunol [17]); 5) Coupling of Horner-Wadsworth-Emmons (HWE) (synthesis of metachromin A [18]). All these structures are shown in Figure 1.

Figure 1. Structure of some natural terpenyl-(hydro)quinones.

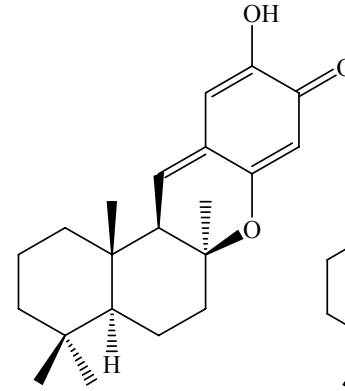

(+)-Puupehenone

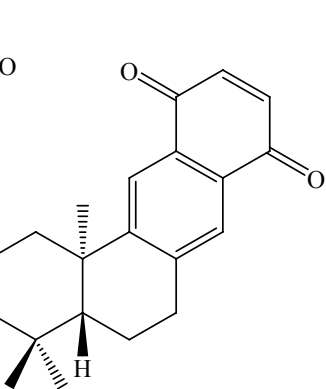

(-)-Cyclozonarone

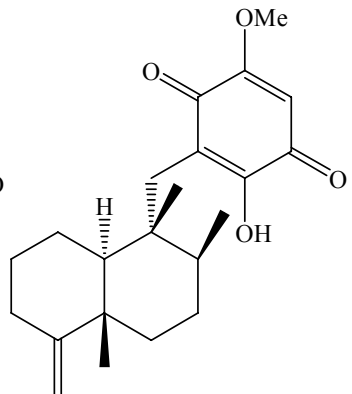

(-)-Ilimaquinone

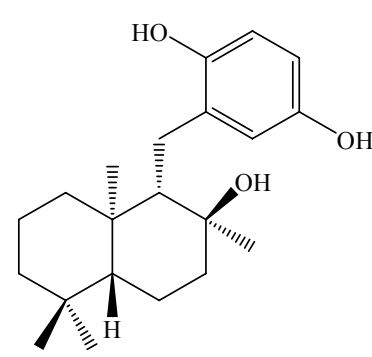

(-)-Yahazunol<smiles>C=C1[C@H](C)CCC[C@]1(C)CC/C(C)=C/CC1=C(O)C(=O)C=C(OC)C1=O</smiles>

Metachromin A

In this work we report the first synthesis and the structural determination of two new bicyclic diterpenyl-hydroquinones $\mathbf{1}$ and $\mathbf{2}$ (Schemes 1 and 2) with ent-labdane skeletons and a bridge between the terpenyl unit and hydroquinonic nuclei consisting of five carbon atoms and an (E)-trisubstituted double bond, as found in the structure of metachromin $\mathbf{A}$. 
For the coupling reaction (key step of the synthesis) between both fragments, a strategy involving Electrophilic Aromatic Substitution (EAS) of diterpenyl allylic alcohol derivatives 5-8 (Figure 2) and diols 9-10 with 1,4-hydroquinone were used, as was described for the synthesis of a taondiol derivative [19-20], although it is important to emphasize that the use of an EAS reaction as the like key coupling reaction step has not been previously reported for the syntheses of terpenylquinones. The results of the biological activities against cancer cellular lines of these compounds will be reported in complete detail elsewhere at a later date.

Figure 2. Structure of natural ent-labdanes and derivatives.
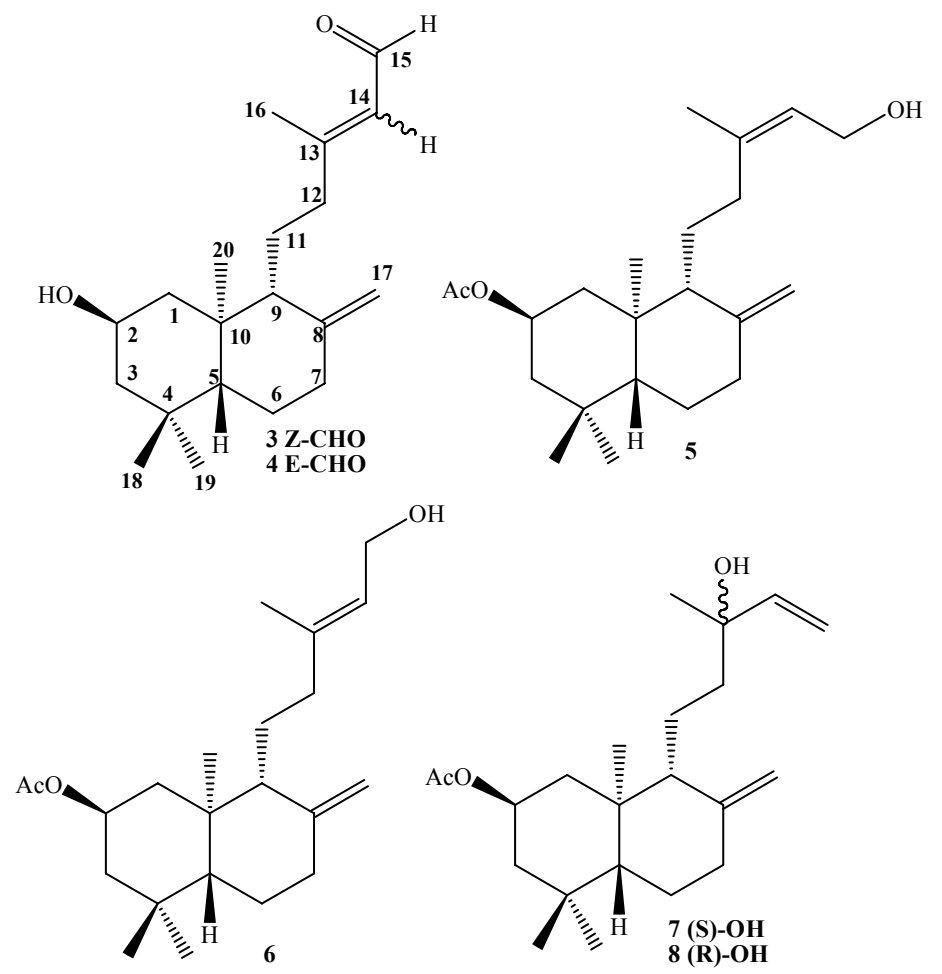

\section{Results and Discussion}

In previous investigations we reported the isolation and structural determination of the mixture of ent-labdanes 3-4 from Calceolaria inamoena and the preparation of derivatives 5 and 6 (Figure 2) [22]. Our next step was the preparation of the tertiary alcohol $\mathbf{7}$ and/or $\mathbf{8}$, from primary allyl alcohols 5 or 6. Nevertheless, when these compounds or a mixture of both, were reacted with $\mathrm{SOCl}_{2}$, in the three cases small amounts of the epimeric mixture 7-8 was obtained (see Scheme 1) along with a complex unidentified mixture of compounds which was obtained as the major component. The highest yield of 7-8 mixture (33.7\%) was observed when compound 6 was treated with $\mathrm{SOCl}_{2}$. Unfortunately this mixture could not be separated by conventional chromatography and the proportion of epimers in the mixture were determined as 7:8 $=0.8: 1$ (ratio calculated based on the integrals of the Me-20 signals in the ${ }^{1} \mathrm{H}-\mathrm{NMR}$ spectrum). The stereochemistry determination for the $\mathrm{C}-13$ position was proposed by comparison and correlations with $\delta^{13} \mathrm{C}$ data of both epimers $\left(\delta_{\mathrm{C}}=73.4\right.$ for 7 and $\delta_{\mathrm{C}}=73.6 \mathrm{ppm}$ for 8$)$ with those reported for other related compounds [22-23], such as (-)-S-sclareol, (+)-R-sclareol, (-)-R- 
manool and $(+)-S$-manool, where the $\mathrm{C}-13$ of the 13-(R) epimer always showed a greater chemical shift than the corresponding 13-(S) epimer.

Scheme 1. Synthesis of compound 1.

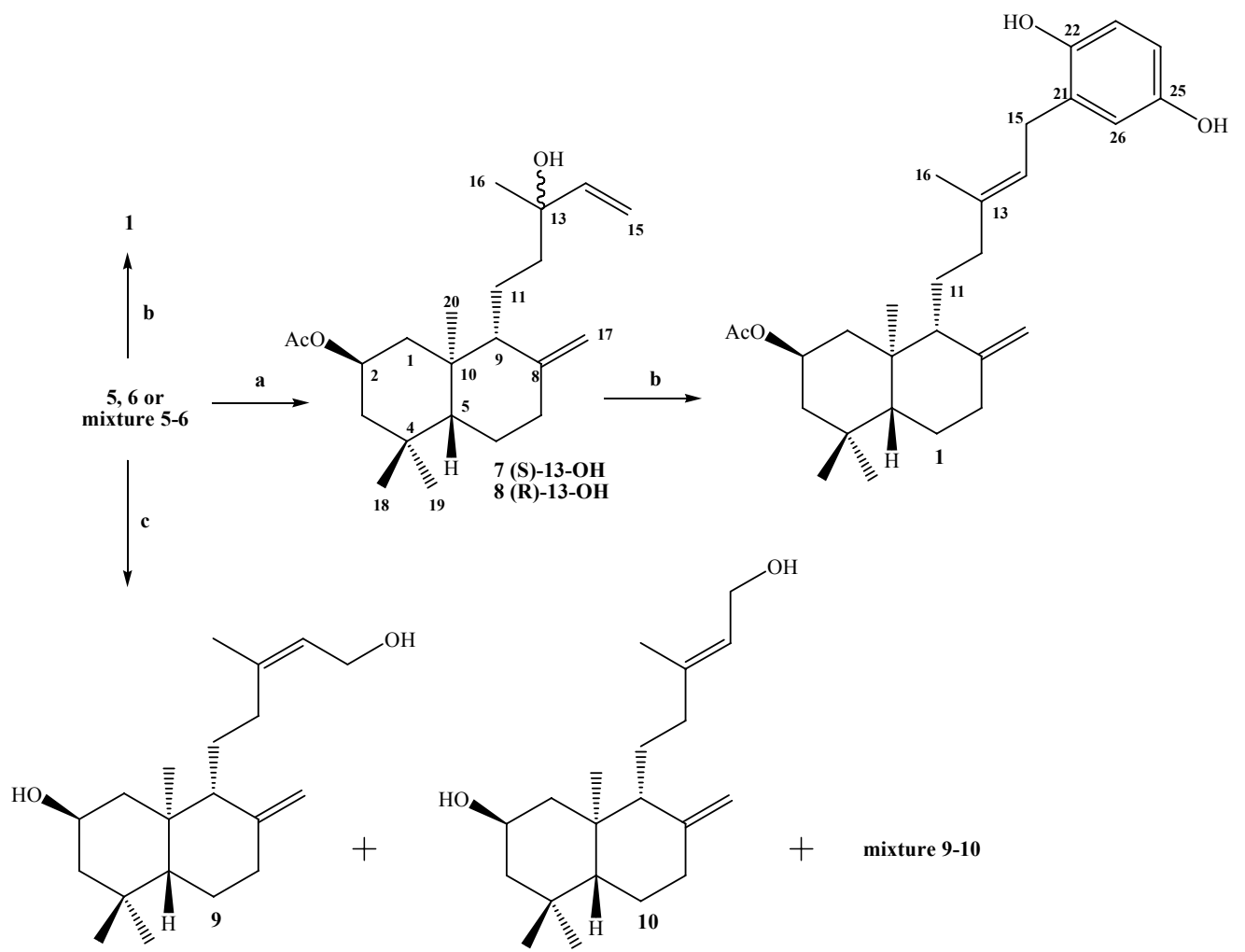

Conditions and reagents: a. From 5: $\mathrm{SOCl}_{2} / \mathrm{CH}_{2} \mathrm{Cl}_{2} / \mathrm{py}, \mathrm{N}_{2}, \mathrm{~T}=-10^{\circ} \mathrm{C}, 1 \mathrm{~h}, 22.1 \%$; from 6: $33.7 \%$; from 5-6: 30.3\%. b. From 5-6: 1,4-hydroquinone/1,4-dioxane $/ \mathrm{BF}_{3} \mathrm{THF}, \mathrm{N}_{2}, \mathrm{~T}=20^{\circ} \mathrm{C}, 24 \mathrm{~h}, 11 \%$; from 5: $10 \%$ and from 6: $20 \%$. c. From 5-6: $\mathrm{K}_{2} \mathrm{CO}_{3} / \mathrm{MeOH}$, r.t, 0.5 h, C.C., 9, $11.3 \%$; 9-10, $20.4 \%$ and $\mathbf{1 0}, 55.4 \%$.

The next step was the coupling reaction between the 7-8 mixture with 1,4-hydroquinone catalyzed by $\mathrm{BF}_{3} \mathrm{THF}$, according to the previously described protocol [19-20]. After the corresponding workup and purification of the crude product by column chromatography $(\mathrm{CC})$, only two major products were isolated: $0.678 \mathrm{~g}$ of an unidentified complex mixture (non-polar fraction) and $0.127 \mathrm{~g}(11 \%)$ of the desired compound $\mathbf{1}$. The structural determination of compound $\mathbf{1}$ was mainly accomplished by ${ }^{1} \mathrm{H}-$, ${ }^{13}$ C-, DEPT-135, gs-2D HSQC and gs-2D HMBC NMR techniques. In its IR spectrum absorptions at 3,401 and $1,701 \mathrm{~cm}^{-1}$ were observed, whereas the ${ }^{1} \mathrm{H}-\mathrm{NMR}$ spectrum showed the existence of three aromatic hydrogens at $\delta=6.67(\mathrm{~d}, J=8.6 \mathrm{~Hz}, 1 \mathrm{H}, \mathrm{H}-23) ; 6.62(\mathrm{~d}, J=3.0 \mathrm{~Hz}, 1 \mathrm{H}, \mathrm{H}-26)$ and 6.57 (dd, $J=8.6$ and $3.0 \mathrm{~Hz}, 1 \mathrm{H}, \mathrm{H}-24)$ and in the ${ }^{13} \mathrm{C}-\mathrm{NMR}$ spectrum the presence of six aromatic carbons was also observed. In addition, the signal at $3.29 \mathrm{ppm}(\mathrm{d}, J=7.1 \mathrm{~Hz}, 2 \mathrm{H}, \mathrm{H}-15)$ correlated (by 2D HSQC) with a carbon atom at $\delta 29.3 \mathrm{ppm}$ (C-15), indicating the coupling point between the diterpenyl fragment and the aromatic nucleus. These data also were corroborated by 2D HMBC correlations, where $\mathrm{H}-15$ showed heteronuclear ${ }^{3} J$ correlations with the carbon signals at $\delta 116.5$ (C-26), 138.5 (C13) and $147.8(\mathrm{C}-22) \mathrm{ppm}$. Heteronuclear ${ }^{2} J$ correlations also were observed at $\delta 121.3(\mathrm{C}-14)$ and 128.3 (C-21), these and some 2D HMBC important correlations are shown in Figure 3a. 
The E-geometrical spatial orientation of the trisubstituted double bond in C13-C14, was deduced from gs-sel- ${ }^{1} \mathrm{H}$ 1D-NOESY experiments: when H-15 was selectively irradiated, long range interactions (strong) with the Me-16 group (1.73 ppm) and H-26 (6.62 ppm) were observed, whereas H-14 showed long range interactions (medium) with $\mathrm{H}-26, \mathrm{H}-12 \mathrm{a}(1.84 \mathrm{ppm})$ and $\mathrm{H}-12 \mathrm{~b}(2.17 \mathrm{ppm}$ ) (see figure $3 \mathrm{~b}$ and $3 \mathrm{c})$.

Figure 3. Structure of compound 1. (a) HMBC correlations. (b) NOE correlations. (c) bottom: normal ${ }^{1} \mathrm{H}-\mathrm{NMR}$ spectrum, middle: selective irradiation at $=3.18 \mathrm{ppm}$, top: selective irradiation at $=5.23 \mathrm{ppm}$ (the sel. gs. 1D ${ }^{1} \mathrm{H}-\mathrm{NOESY}$ spectra were registered using selnogp. 3 Bruker pulse program and parameter set: $\mathrm{ns}=32, \mathrm{p} 12=80 \mathrm{~ms}$ and $\mathrm{d} 8=$ $400 \mathrm{~ms})$.
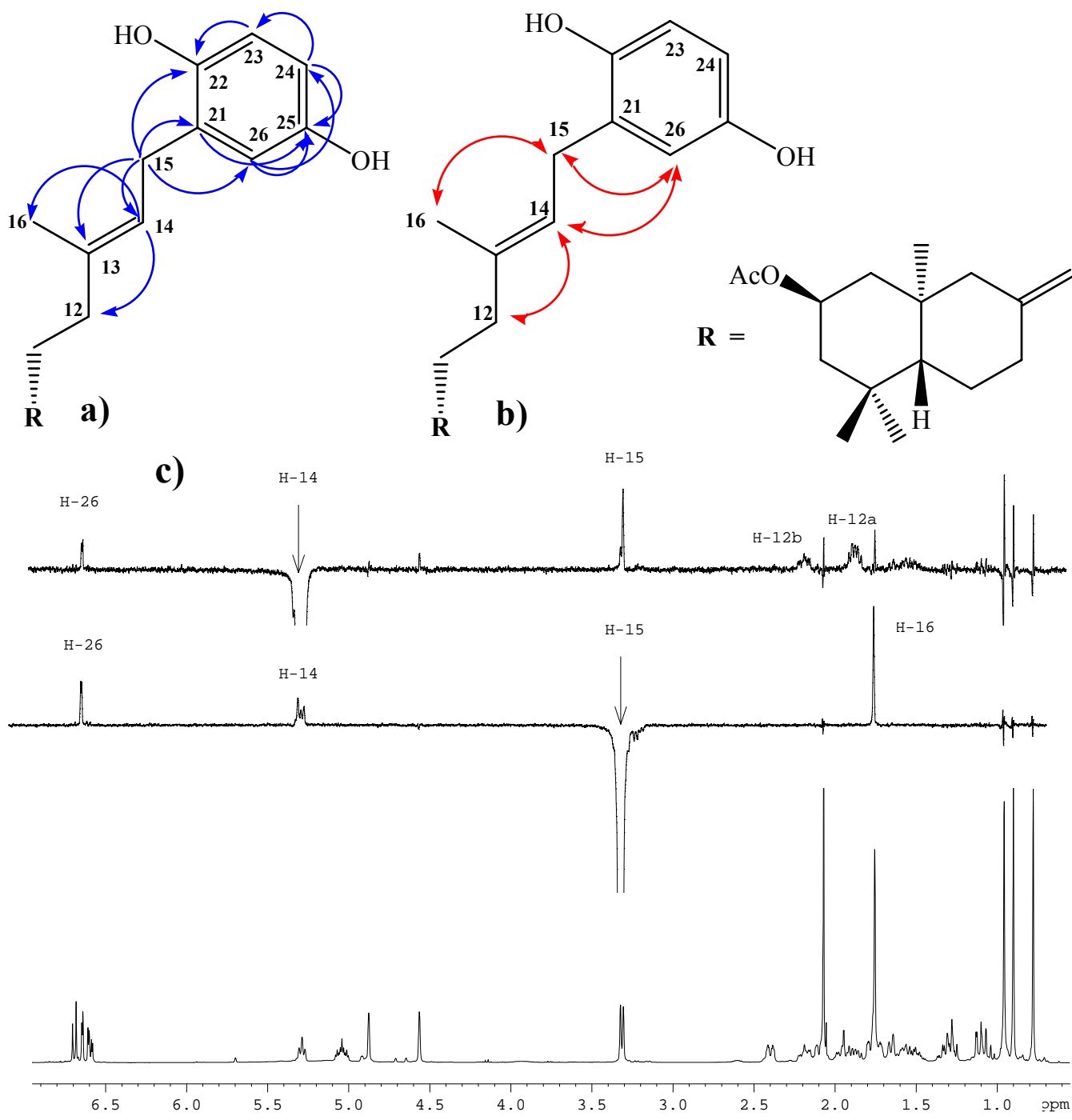

Additionally we decided to try the coupling reaction with 1,4-hydroquinone separately, using the compounds 5, 6 and a mixture of both (see Scheme 1), following the previously protocol described for the 7-8 mixture. In the case of alcohol 5 (1.39 g), after usual workup followed of CC separation, three fractions were obtained: $1.33 \mathrm{~g}$ of a non-identified complex mixture (non-polar fraction), $0.175 \mathrm{~g} \mathrm{(10 \%}$ yield) of compound 1 and $0.37 \mathrm{~g}$ of unreacted 1,4-hydroqinone. In the case of alcohol 6 (1.54 g) were obtained: $0.983 \mathrm{~g}$ of complex mixture, $0.390 \mathrm{~g}$ ( $20 \%$ yield) of compound 1 and $0.28 \mathrm{~g}$ of unreacted 
1,4-hydroquinone. In the case of a 5-6 mixture (3.92 g, approx. ratio 5:6 $=0.25: 0.75) 2.47 \mathrm{~g}$ of complex mixture, $1.29 \mathrm{~g}$ ( $26 \%$ yield) of compound 1 and $0.963 \mathrm{~g}$ of unreacted 1,4-hydroquinone were obtained. The characterization of compound 1 was accomplished by simple inspection and comparison of ${ }^{1} \mathrm{H}$ - and ${ }^{13} \mathrm{C}$-NMR spectral data with that previously obtained.

We also performed the coupling reaction using the diols $\mathbf{9 , 1 0}$ and a mixture of both (see Scheme 1) following the experimental procedure previously described. The diols were obtained by alkaline hydrolysis with $\mathrm{K}_{2} \mathrm{CO}_{3} / \mathrm{MeOH}$, acidification and later separation and purification by CC. From $2.93 \mathrm{~g}$ of the acetate mixture 5-6, $0.292 \mathrm{~g}$ of diol 9 (11.3\% yield), $0.527 \mathrm{~g}$ (yield 20.4\%) of a 9-10 mixture and $1.43 \mathrm{~g}$ (55.4\% yield) of diol $\mathbf{1 0}$ were obtained. The structures of compounds $\mathbf{9}$ and $\mathbf{1 0}$ were mainly established by ${ }^{1} \mathrm{H}$ - and ${ }^{13} \mathrm{C}$-NMR spectroscopic data (see Experimental section) and compared with those reported for acetates $\mathbf{5}$ and $\mathbf{6}$, respectively [21]. The proportion of geometrical isomers in the mixture were determined as 9:10 $=0.2: 1$ (ratio calculated based on the integrals of the $\mathrm{H}-17 \mathrm{a}$ and $\mathrm{H}$ $17 \mathrm{~b}$ signals in the ${ }^{1} \mathrm{H}-\mathrm{NMR}$ spectrum). When compound 9 (0.238 g) was reacted with 1,4hydroquinone, a non polar unidentified complex mixture $(0.183 \mathrm{~g})$ and $40 \mathrm{mg}(13 \%)$ of compound 2 were obtained. From the compound $\mathbf{1 0}(0.897 \mathrm{~g}) 0.420 \mathrm{~g}$ of complex mixture and $0.246 \mathrm{~g}(21 \%)$ of compound 2 were obtained. On the other hand, from 9-10 mixture $(0.258 \mathrm{~g}) 0.122 \mathrm{~g}$ of the complex mixture, $57 \mathrm{mg}$ (17\%) of diol 11 and $94 \mathrm{mg}$ (28\%) of compound 2 were isolated (see Scheme 2).

Scheme 2. Synthesis of compounds 2 and 11.

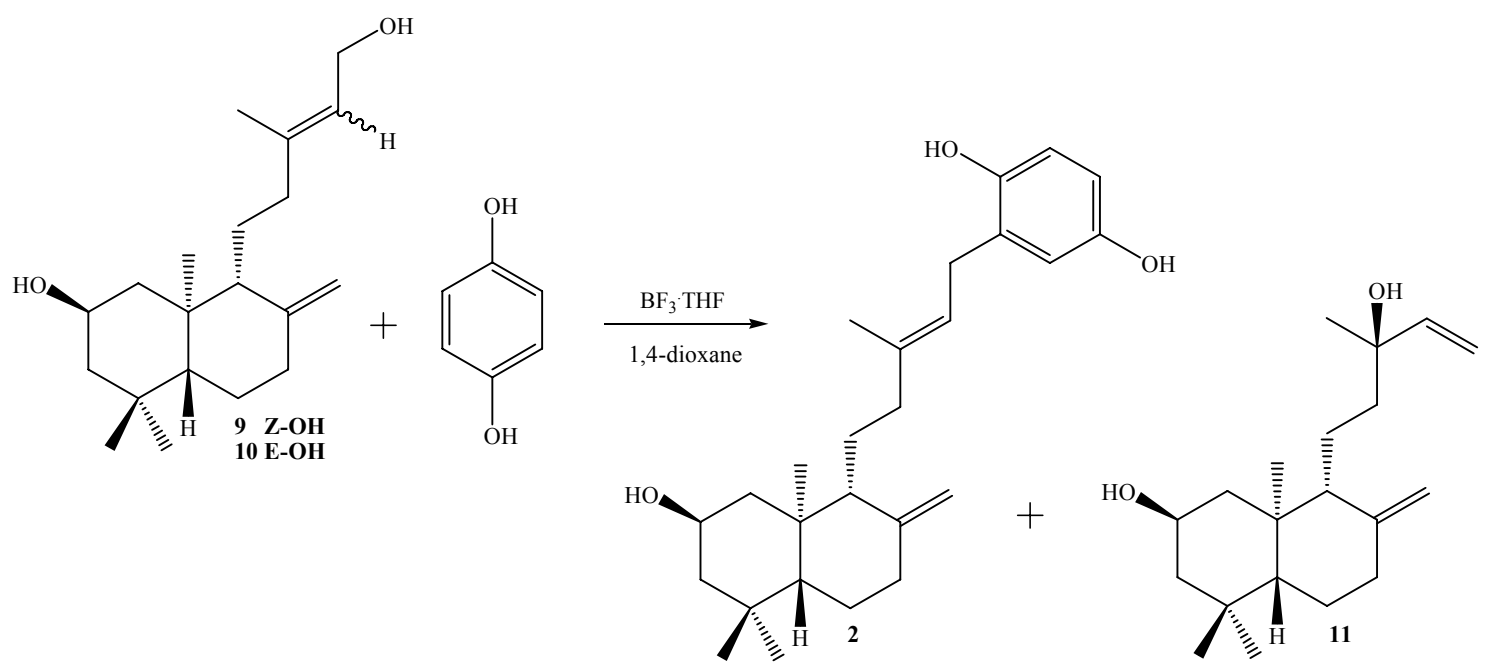

Conditions: From 9: $\mathrm{N}_{2}, \mathrm{~T}=20^{\circ} \mathrm{C}, 24 \mathrm{~h}, 13 \%$; from 10: $21 \%$; and from 9-10 mixture: 11, $17 \%$ and 2, $28 \%$.

The structural determination of compound 2 was established by comparison of the spectral data of compound $\mathbf{1}$ and using the same criteria. In the IR spectrum of compound $\mathbf{2}$ a strong absorption at $3,375 \mathrm{~cm}^{-1}$ was mainly observed, whereas the ${ }^{1} \mathrm{H}-\mathrm{NMR}$ spectrum showed the existence of three aromatic hydrogens at $\delta=6.67(\mathrm{~d}, J=8.6 \mathrm{~Hz}, 1 \mathrm{H}, \mathrm{H}-23) ; 6.64(\mathrm{~d}, J=2.9 \mathrm{~Hz}, 1 \mathrm{H}, \mathrm{H}-26)$ and $6.57(\mathrm{dd}$, $J=8.6$ and $2.9 \mathrm{~Hz}, 1 \mathrm{H}, \mathrm{H}-24)$, while in the ${ }^{13} \mathrm{C}-\mathrm{NMR}$ spectrum the presence of six aromatic carbons also was observed. In addition the signal at $3.29 \mathrm{ppm}(\mathrm{d}, J=7.1 \mathrm{~Hz}, 2 \mathrm{H}, \mathrm{H}-15)$ correlated (by 2D HSQC) with a carbon atom at $\delta 29.0 \mathrm{ppm}$ (C-15), indicating the coupling point between the diterpenyl fragment and the aromatic nucleus. These data also were corroborated by $2 \mathrm{D}$ HMBC correlations, 
where $\mathrm{H}-15$ showed heteronuclear ${ }^{3} J$ correlations with the carbons signal at $\delta 116.6$ (C-26), 138.1 (C$13)$ and $147.7(\mathrm{C}-22) \mathrm{ppm}$. Heteronuclear ${ }^{2} J$ correlations were also observed at $\delta 121.7(\mathrm{C}-14)$ and $128.6(\mathrm{C}-21)$.

The structure of compound $\mathbf{1 1}$ was established by spectroscopic correlations of its ${ }^{1} \mathrm{H}$ - and ${ }^{13} \mathrm{C}$ NMR data with the 7-8 mixture and the stereochemistry in C-13 position was tentatively assigned as " $R$ " by comparison and correlations with $\delta{ }^{13} \mathrm{C}$ data of epimers 7 and $\mathbf{8}$, which showed a chemical shift at $\delta_{\mathrm{C}}=73.5 \mathrm{ppm}$ for this carbon.

As previously indicated in all the coupling reactions, the formation of a complex mixture of products was observed. Nevertheless by simple inspection of the ${ }^{1} \mathrm{H}$ - and ${ }^{13} \mathrm{C}-\mathrm{NMR}$ spectra of this mixture, we observed the presence of hydrogen $\left(\delta_{\mathrm{H}}: 6.45-6.14 \mathrm{ppm}\right)$ and carbon $\left(\delta_{\mathrm{C}}: 150.6-142.4 \mathrm{ppm}\right)$ vinyl signals that were probably due to the formation of mixtures of alkenes (IV and $\mathbf{V}$ ), presumably obtained via formation of a cationic intermediary III (formed by reaction of the allyl alcohols with $\mathrm{BF}_{3} \cdot \mathrm{THF}$, followed by rearrangement of intermediate $\mathbf{I}$ and/or $\mathbf{I I}$ ), later elimination $E_{1}$ products or in one case $S N_{1}$ (for example the formation of compound 11), that compete with the formation of Electrophilic Aromatic Substitution (EAS) products (see Figure 4)

Figure 4. General schemes with probable intermediaries of reaction II and III and $E_{1}$ elimination products, which would be competing with the desired coupling reaction via EAS.

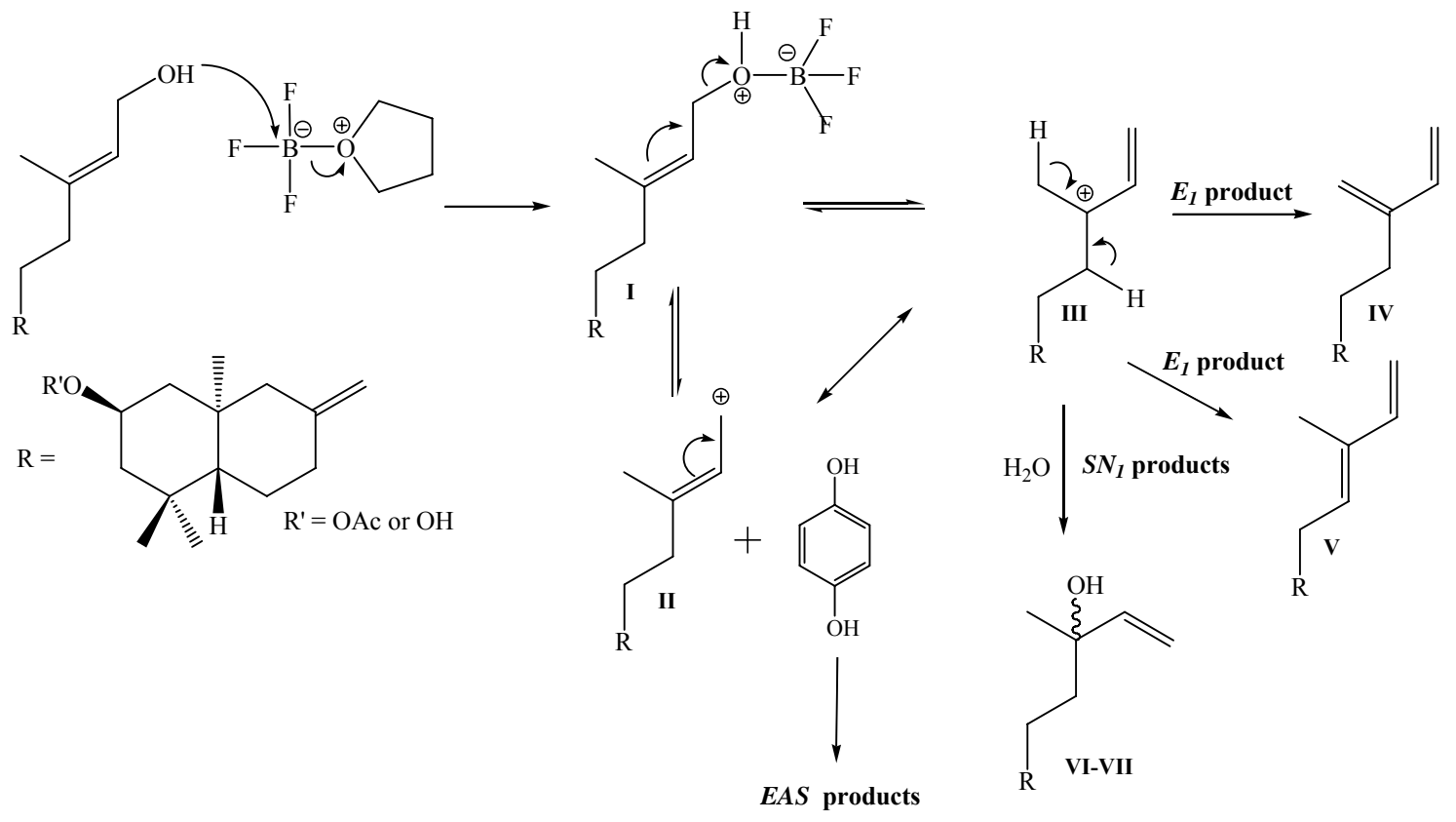

\section{Conclusions}

In this work we have described the synthesis and structural determination of two new diterpenylhydroquinones from natural ent-labdanes. These compounds were obtained by coupling primary or tertiary allyl alcohol ent-labdane derivatives with 1,4-hydroquinone by Electrophilic Aromatic Substitution (EAS). This method of coupling between terpenyl fragments and aromatic nucleus (key step in all synthesis of terpenyl-(hydro)quinones) had not been previously described, and worked for all the allylic alcohols used here. Nevertheless, the best results were observed when the mixtures of 
primary alcohols 5-6 (26\% yield of compound 1) and mixture of diols 9-10 (28\% yield of compound 2) were used for coupling reaction. We think that the possible formation of very stable intermediary III (Figure 4) is mainly responsible for the formation of a complex mixture of alkenes and the low yields observed in the coupling reactions.

\section{Experimental}

\section{General}

Unless otherwise stated, all chemical reagents purchased (Merck or Aldrich) were of the highest commercially available purity and were used without previous purification. Melting points were measured (in triplicate) on a Stuart-Scientific SMP3 apparatus and are uncorrected. IR spectra were recorded as thin films in a Nicolet Impact 420 spectrometer and frequencies are reported in $\mathrm{cm}^{-1}$. Optical rotations were measured with a sodium lamp ( $\lambda=589 \mathrm{~nm}, \mathrm{D}$ line) on a Perkin Elmer 241 digital polarimeter equipped with $1 \mathrm{dm}$ cells at the temperature indicated in each case. Low resolution mass spectra were recorded on a Shimadzu QP-2000 spectrometer at 70eV ionising voltage and are given as $\mathrm{m} / \mathrm{z}$ (\% rel. int.) ${ }^{1} \mathrm{H}-,{ }^{13} \mathrm{C}$ - (DEPT 135 and DEPT 90), sel. 1D ${ }^{1} \mathrm{H}$ NOESY, sel. 1D ${ }^{1} \mathrm{H}$ TOCSY, 2D HSQC and 2D HMBC spectra were recorded in $\mathrm{CDCl}_{3}$ solutions and are referenced to the residual peaks of $\mathrm{CHCl}_{3}$ at $\delta 7.26 \mathrm{ppm}$ and $\delta 77.0 \mathrm{ppm}$ for ${ }^{1} \mathrm{H}$ and ${ }^{13} \mathrm{C}$, respectively, on a Bruker Avance 400 Digital NMR spectrometer, operating at $400.1 \mathrm{MHz}$ for ${ }^{1} \mathrm{H}$ and $100.6 \mathrm{MHz}$ for ${ }^{13} \mathrm{C}$. Chemical shifts are reported in $\delta$ ppm and coupling constants $(J)$ are given in Hz. Silica gel (Merck 200-300 mesh) was used for C.C. and silica gel plates HF-254 for TLC. TLC spots were detected by heating after spraying with $25 \% \mathrm{H}_{2} \mathrm{SO}_{4}$ in $\mathrm{H}_{2} \mathrm{O}$.

Synthesis of $2 \beta$-acetoxy-(S)-13-hydroxy-ent-labda-8(17), 14-diene (7) and 23-acetoxy-(R)-13-hydroxyent-labda-8(17), 14-diene (8) from 5: A solution of 5 (1.54 g, $0.44 \mathrm{mmol})$ in dry $\mathrm{CH}_{2} \mathrm{Cl}_{2}(50 \mathrm{~mL})$ and dry pyridine $(1 \mathrm{~mL})$, was prepared under a $\mathrm{N}_{2}$ atmosphere and cooled to $-10^{\circ} \mathrm{C}$ (ice/acetone/brine bath). Then $\mathrm{SOCl}_{2}(0.6 \mathrm{~mL}, 8.26 \mathrm{mmol})$ was slowly added dropwise while maintaining slow agitation. After one hour, the completion of the reaction were verified by TLC. Then saturated aqueous solution of $\mathrm{NaHCO}_{3}(50 \mathrm{~mL})$ was added and the mixture was extracted with EtOAc $(2 \times 25 \mathrm{~mL})$ and the combined organic layers were washed with water $(2 \times 20 \mathrm{~mL})$, dried over $\mathrm{Na}_{2} \mathrm{SO}_{4}$, filtered and evaporated. The crude was redissolved in $\mathrm{CH}_{2} \mathrm{Cl}_{2}(5 \mathrm{~mL})$ and chromatographed on silica-gel with petroleum ether/EtOAc mixtures of increasing polarity $(19.8: 0.2 \rightarrow 8.8: 11.2)$. Two fractions were obtained: Fraction I: $1.08 \mathrm{~g}$ of a non-polar unidentified complex mixture (colorless viscous oil) Fraction II: colorless viscous oil, $0.34 \mathrm{~g}(22.1 \%)$ of a mixture of 7-8.

Synthesis of 7-8 mixture from 6: From $2.23 \mathrm{~g}$ (6.40 mmol) of alcohol 6, $0.8 \mathrm{~mL}(11.0 \mathrm{mmol})$ of $\mathrm{SOCl}_{2}$ and $1.5 \mathrm{~mL}$ of pyridine, $1.32 \mathrm{~g}$ of non-polar complex mixture and $0.75 \mathrm{~g}(33.7 \%)$ of 7-8 mixture were obtained.

Synthesis of 7-8 mixture from a mixture of 5-6: From $2.38 \mathrm{~g}(6.83 \mathrm{mmol})$ of 5-6 mixture, $0.8 \mathrm{~mL}$ $(11.0 \mathrm{mmol})$ of $\mathrm{SOCl}_{2}$ and $1.5 \mathrm{~mL}$ of pyridine, $1.57 \mathrm{~g}$ of non-polar complex mixture and $0.72 \mathrm{~g}(30.3 \%)$ of 7-8 mixture were obtained. 
Compound 7: ${ }^{1} \mathrm{H}-\mathrm{NMR}: 5.90(\mathrm{dd}, J=17.3$ and $10.8 \mathrm{~Hz}, 1 \mathrm{H}, \mathrm{H}-14) ; 5.20$ (dd, $J=17.3$ and $1.5 \mathrm{~Hz}$, $1 \mathrm{H}, \mathrm{H}-15 \mathrm{~b}$ ); 5.05 (dd, $J=10.8$ and $1.5 \mathrm{~Hz}, 1 \mathrm{H}, \mathrm{H}-15 \mathrm{a}$ ); 5.02 (ddt, $J=11.7,11.7$ and $3.9 \mathrm{~Hz}, 1 \mathrm{H}, \mathrm{H}-2$ ); 4.89 (s, 1H, H-17b); 4.55 (s, 1H, H-17a); 2.39. (ddd, $J=12.7,4.4$ and $2.5 \mathrm{~Hz}, 1 \mathrm{H}, \mathrm{H}-7 \alpha$ ); 2.07 (m, 1H, $\mathrm{H}-1 \alpha$ ); 2.03 (s, 3H, $\mathrm{CH}_{3} \mathrm{CO}_{2}$ ); 1.95 (ddd, $J=13.2,12.7$ and $\left.4.9 \mathrm{~Hz}, 1 \mathrm{H}, \mathrm{H}-7 \beta\right) ; 1.70$ (m, 3H, H-3 $\alpha, \mathrm{H}-$ $12 \mathrm{~b}$ and $\mathrm{H}-6 \beta$ ); 1.61 (bd, $J=10.3 \mathrm{~Hz}, 1 \mathrm{H}, \mathrm{H}-9) ; 1.43$ (m, 1H, H-11b); 1.32 (m, 1H, H-11a); 1.29 (m,

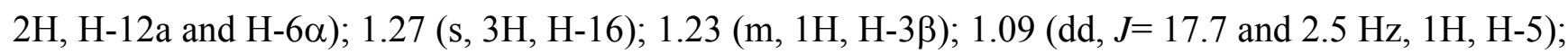
1.07 (dd, $J=11.7$ and $11.7 \mathrm{~Hz}, 1 \mathrm{H}, \mathrm{H}-1 \beta), 0.93$ (s, 3H, H-18); 0.88 (s, 3H, H-19); 0.76 (s, 3H, H-20); ${ }^{13}$ C-NMR: 44.1 (C-1), 69.3 (C-2), 46.8 (C-3), 34.9 (C-4), 55.0 (C-5), 23.9 (C-6), 38.0 (C-7), 147.4 (C8), 57.1 (C-9), 41.2 (C-10), 17.9 (C-11), 41.1 (C-12), 73.4 (C-13), 145.2 (C-14), 111.7 (C-15), 27.5 (C16). 107.6 (C-17), 33.6 (C-18), 22.4 (C-19), 15.2 (C-20), $170.6\left(\mathrm{CH}_{3} \underline{\mathrm{CO}}\right), 21.5\left(\mathrm{CH}_{3} \mathrm{CO}\right) ; \mathrm{M} . \mathrm{S} .(\mathrm{m} / \mathrm{z}$, \%): $\mathrm{M}^{+} 348$ (<1\%), 202 (13.2); 201 (13.9); 189 (13.9); 188 (20.8); 187 (33.0); 175 (16.0); 173 (8.9); 161 (10.5); 159 (12.8); 147 (11.4); 136 (14.5); 135 (100); 134 (15.9); 133 (17.2); 131 (12.2); 122 (10.5); 121 (27.1); 120 (15.0); 119 (28.0); 109 (13.8); 107 (32.3); 105 (14.8); 95 (18.3); 94 (9.4); 93 (29.9); 91 (18.1); 81 (21.1); 80 (8.9); 79 (18.0); 71 (22.5).

Compound 8: ${ }^{1} \mathrm{H}-\mathrm{NMR}: 5.90(\mathrm{dd}, J=17.4$ and $10.8 \mathrm{~Hz}, 1 \mathrm{H}, \mathrm{H}-14) ; 5.21$ (dd, $J=17.4$ and $1.0 \mathrm{~Hz}$, $1 \mathrm{H}, \mathrm{H}-15 \mathrm{~b}$ ); 5.06 (dd, $J=10.8$ and $1.0 \mathrm{~Hz}, 1 \mathrm{H}, \mathrm{H}-15 \mathrm{a}) ; 5.02$ (ddt, $J=11.7,11.7$ and $3.9 \mathrm{~Hz}, 1 \mathrm{H}, \mathrm{H}-2$ ); 4.84 (s, 1H, H-17b); 4.50 (s, 1H, H-17a); 2.39 (ddd, $J=12.7,4.4$ and $2.5 \mathrm{~Hz}, 1 \mathrm{H}, \mathrm{H}-7 \alpha) ; 2.07$ (m, 1H, $\mathrm{H}-1 \alpha$ ); 2.03 (s, 3H, $\mathrm{CH}_{3} \mathrm{CO}_{2}$ ); 1.95 (ddd, $J=13.2,12.7$ and $\left.4.9 \mathrm{~Hz}, 1 \mathrm{H}, \mathrm{H}-7 \beta\right) ; 1.70$ (m, 3H, H-3 $\alpha, \mathrm{H}-$ $12 \mathrm{~b}$ and $\mathrm{H}-6 \beta$ ); 1.61 (bd, $J=10.3 \mathrm{~Hz}, 1 \mathrm{H}, \mathrm{H}-9) ; 1.43$ (m, 1H, H-11b); 1.32 (m, 1H, H-11a); 1.27 (m,

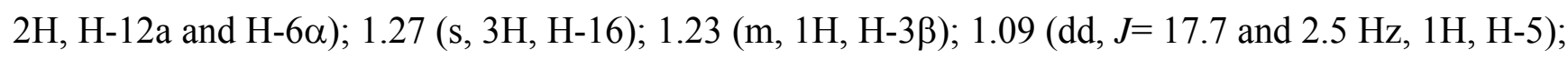
1.07 (dd, $J=11.7$ and $11.7 \mathrm{~Hz}, 1 \mathrm{H}, \mathrm{H}-1 \beta), 1.04$ (s, 3H, H-18); 0.88 (s, 3H, H-19); 0.75 (s, 3H, H-20). ${ }^{13} \mathrm{C}-\mathrm{NMR}: 44.2$ (C-1), 69.3 (C-2), 46.8 (C-3), 34.9 (C-4), 55.0 (C-5), 23.9 (C-6), 38.0 (C-7), 147.5 (C8), 57.0 (C-9), 41.1 (C-10), 17.8 (C-11), 41.2 (C-12), 73.6 (C-13), 145.0 (C-14), 111.8 (C-15), 28.3 (C16). 107.4 (C-17), 33.6 (C-18), 22.4 (C-19), 15.2 (C-20), $170.6\left(\mathrm{CH}_{3} \underline{\mathrm{CO}}\right), 21.5\left(\underline{\mathrm{CH}}_{3} \mathrm{CO}\right) . \mathrm{M} . \mathrm{S} .(\mathrm{m} / \mathrm{z}$, \%): $\mathrm{M}^{+} 348(<1 \%), 302$ (4.9); 270 (10.3); 255 (28.2); 136 (14.8); 135 (100); 134 (16.8); 133 (17); 122 (10.9); 121 (26.9); 120 (14.7); 119 (27.3); 109 (13.2); 107 (31.6); 105 (21.6); 95 (18.1); 93 (29.0); 91 (17.7); 81 (20.2); 79 (17.6); 71 (22.0). Mixture 7-8, IR ( $\left.\mathrm{cm}^{-1}\right): 3,483,3,069,2,960,1,736,1,721,1,644$, $1,470,1,368,1,255,1,209$.

Synthesis of 2 $\beta$-acetoxy-15-phenyl-(22,25-dihydroxy)-ent-labda-8(17),13(E)-diene (1) from 7-8 mixture: To a solution of 1,4-hydroquinone $(0.30 \mathrm{~g}, 2.27 \mathrm{mmol})$ and $\mathrm{BF}_{3} \cdot \mathrm{THF}(0.5 \mathrm{~mL}, 3.98 \mathrm{mmol})$ in freshly distilled 1,4-dioxane $(5 \mathrm{~mL})$ was slowly added dropwise, with stirring at room temperature and under a $\mathrm{N}_{2}$ atmosphere, a solution of 7-8 mixture $(0.91 \mathrm{~g}, 2.61 \mathrm{mmol})$ in 1,4-dioxane $(5 \mathrm{~mL})$. After the addition was complete, stirring at room temperature and under $\mathrm{N}_{2}$ atmosphere was continued overnight. When the completion of the reaction was verified by TLC, the mixture was poured onto crushed ice (app. $30 \mathrm{~g}$ ) and the organic layer extracted with diethyl ether $(3 \times 30 \mathrm{~mL})$, the ethereal layer was washed with $5 \% \mathrm{NaHCO}_{3}(30 \mathrm{~mL})$, then with water $(2 \times 20 \mathrm{~mL})$ and dried over $\mathrm{Na}_{2} \mathrm{SO}_{4}$, filtered and evaporated. The crude was redissolved in $\mathrm{CH}_{2} \mathrm{Cl}_{2}(5 \mathrm{~mL})$ and chromatographed on silicagel with petroleum ether/EtOAc mixtures of increasing polarity $(19.8: 0.2 \rightarrow 11.4: 8.6)$. Three fractions were obtained: Fraction I: $0.678 \mathrm{~g}$ of non-polar non-identified complex mixture (colorless viscous oil) Fraction II: colorless viscous oil, $0.127 \mathrm{~g}$ (11\%) of compound 1, and Fraction III: $8.0 \mathrm{mg}$ of unreacted 1,4-hydroquinone. 
Synthesis of 1 from 5: 1,4-hydroquinone (0.50 g, $4.54 \mathrm{mmol}), \mathrm{BF}_{3} \mathrm{THF}(0.5 \mathrm{~mL}, 3.98 \mathrm{mmol})$ and 5 $(1.39 \mathrm{~g}, 3.96 \mathrm{mmol})$ were used. After workup and CC purification: $1.33 \mathrm{~g}$ of complex mixture, $0.175 \mathrm{~g}$ (10\%) of $\mathbf{1}$ and $0.37 \mathrm{~g}$ of unreacted 1,4-hydroquinone were obtained.

Synthesis 1 from 6: 1,4-hydroquinone (0.50 g, $4.54 \mathrm{mmol}), \mathrm{BF}_{3} \cdot \mathrm{THF}(0.7 \mathrm{~mL}, 5.59 \mathrm{mmol})$ and 6 (1.54 $\mathrm{g}, 4.42 \mathrm{mmol})$ were used. After workup and CC purification: $0.983 \mathrm{~g}$ of complex mixture, $0.39 \mathrm{~g}(20 \%)$ of 1 and $0.28 \mathrm{~g}$ of unreacted 1,4-hydroqinone, were obtained.

Synthesis 1 from 5-6 mixture: 1,4-hydroquinone (1.30 g, $11.8 \mathrm{mmol}), \mathrm{BF}_{3} \cdot \mathrm{THF}(1.5 \mathrm{~mL}, 11.9 \mathrm{mmol})$ and 5-6 mixture (3.92 g, $11.25 \mathrm{mmol})$ were used. After workup and CC purification: $2.47 \mathrm{~g}$ of complex mixture, $1.29 \mathrm{~g} \mathrm{(26 \% )}$ of 1 and $0.963 \mathrm{~g}$ of unreacted 1,4-hydroqinone, were obtained.

Compound 1, colorless viscous oil, $[\alpha]_{\mathrm{D}}{ }^{23}=-2.6^{\circ}\left(\mathrm{c} 1.85, \mathrm{CHCl}_{3}\right) ;{ }^{1} \mathrm{H}-\mathrm{NMR}: 6.67(\mathrm{~d}, J=8.6 \mathrm{~Hz}, 1 \mathrm{H}$, H-23); $6.62(\mathrm{~d}, J=3.0 \mathrm{~Hz}, 1 \mathrm{H}, \mathrm{H}-26) ; 6.57$ (dd, $J=8.6$ and $3.0 \mathrm{~Hz}, 1 \mathrm{H}, \mathrm{H}-24) ; 5.26$ (t, $J=7.1 \mathrm{~Hz}, 1 \mathrm{H}$, H-14); 5.03 (ddt, $J=12.0,12.0$ and $4.2 \mathrm{~Hz}, 1 \mathrm{H}, \mathrm{H}-2$ ); 4.85 (s, 1H, H-17b); 4.54 (s, 1H, H-17a); 3.29 (d, $J=7.1 \mathrm{~Hz}, 2 \mathrm{H}, \mathrm{H}-15) ; 2.38$ (ddd, $J=13.0,4.4$ and $2.5 \mathrm{~Hz}, 1 \mathrm{H}, \mathrm{H}-7 \alpha) ; 2.17$ (ddd, $J=13.9,8.8$ and 4.4 $\mathrm{Hz}, 1 \mathrm{H}, \mathrm{H}-12 \mathrm{~b}) ; 2.06$ (m, $1 \mathrm{H}, \mathrm{H}-1 \alpha) ; 2.05$ (s, 3H, $\mathrm{CH}_{3} \mathrm{CO}_{2}$ ); 1.92 (ddd, $J=13.0,12.5$ and $4.4 \mathrm{~Hz}, 1 \mathrm{H}$,

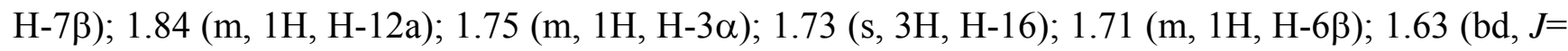

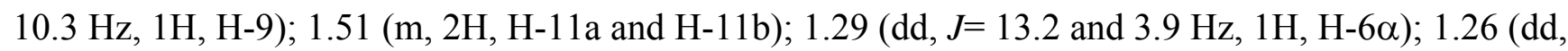
$J=12.0$ and $12.0 \mathrm{~Hz}, 1 \mathrm{H}, \mathrm{H}-3 \beta) ; 1.09$ (dd, $J=13.2$ and $2.5 \mathrm{~Hz}, 1 \mathrm{H}, \mathrm{H}-5) ; 1.05$ (dd, $J=12.0$ and $12.0 \mathrm{~Hz}$, 1H, H-1ß); 0.93 (s, 3H, H-18); 0.88 (s, 3H, H-19); 0.75 (s, 3H, H-20). ${ }^{13} \mathrm{C}-\mathrm{NMR}: 44.0$ (C-1), 69.8 (C2), 46.7 (C-3), 34.9 (C-4), 54.8 (C-5), 23.8 (C-6), 37.9 (C-7), 147.4 (C-8), 55.8 (C-9), 40.9 (C-10), 22.1 (C-11), 38.3 (C-12), 138.5 (C-13), 121.3 (C-14), 29.3 (C-15), 16.3 (C-16), 107.3 (C-17), 33.5 (C18), 22.4 (C-19), 15.2 (C-20), 128.3 (C-21), 147.8 (C-22), 116.3 (C-23), 113.6 (C-24), 149.5 (C-25), 116.5 (C-26), $171.1\left(\mathrm{CH}_{3} \underline{\mathrm{CO}}\right), 21.6\left(\mathrm{CH}_{3} \mathrm{CO}\right) . \mathrm{IR}\left(\mathrm{cm}^{-1}\right): 3,401,2,940,1,701,1,609,1,501,1,450$, 1,367, 1,265, 1,199, 1,020, 958, 892, 753. M.S. (m/z, \%): $\mathrm{M}^{+} 440<1 \%, 288$ (9.0), 274 (11.8), 273 (55.6), 255 (31.8), 202 (14.2), 188 (11.4), 187 (34.1), 175 (21.3), 161 (14.0), 159 (13.5), 135 (100), 119 (36.9), 107 (45.9), 93 (42.1), 91 (26.7), 81 (29.6), 79 (24.6), 77 (11.4), 69 (21.4), 67 (19.1), 55 (21.1).

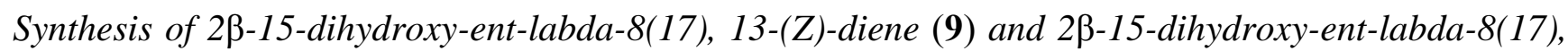
13-(E)-diene (10) from 5-6 mixture: To a solution of 5-6 mixture $(2.93 \mathrm{~g}, 8.41 \mathrm{mmol})$ in $\mathrm{MeOH}(60$ $\mathrm{mL})$, finely divided $\mathrm{K}_{2} \mathrm{CO}_{3}(1.20 \mathrm{~g}, 8.68 \mathrm{mmol})$ was added and the mixture stirred at room temperature for $0.5 \mathrm{~h}$. After the TLC analysis indicated the completion of the reaction, the solvent was removed until a volume of approximately $5 \mathrm{~mL}$ remained and water $(30 \mathrm{~mL})$ was added, then $5 \% \mathrm{HCl}(15 \mathrm{~mL})$ was added, the mixture was extracted with EtOAc $(3 \times 30 \mathrm{~mL})$ and the combined organic layers were washed successively with $10 \% \mathrm{NaHCO}_{3}$ and water, dried over $\mathrm{Na}_{2} \mathrm{SO}_{4}$, filtered and evaporated. The crude $(2.45 \mathrm{~g})$ was redissolved in $\mathrm{CH}_{2} \mathrm{Cl}_{2}(10 \mathrm{~mL})$ and chromatographed eluting with mixtures of petroleum ether/EtOAc of increasing polarity $(19.8: 0.2 \rightarrow 12.2: 7.8)$ to give three fractions.

Fraction I: compound $9(0.292 \mathrm{~g}, 11.3 \%)$ colorless viscous oil, $[\alpha]_{\mathrm{D}}{ }^{23}=-43.5^{\circ}\left(\mathrm{c} 0.96, \mathrm{CHCl}_{3}\right) ;{ }^{1} \mathrm{H}-$ NMR: 5.44 (bt, J=7.1 Hz, 1H, H-14); 4.92 (s, 1H, H-17b); 4.61 (s, 1H, H-17a); 4.08 (dd, J= 7.1 and $2.5 \mathrm{~Hz}, 2 \mathrm{H}, \mathrm{H}-15$ ); 3.90 (ddt, $J=11.5,11.5$ and $4.2 \mathrm{~Hz}, 1 \mathrm{H}, \mathrm{H}-2$ ); 2.43 (ddd, $J=13.0,4.2$ and $2.5 \mathrm{~Hz}$,

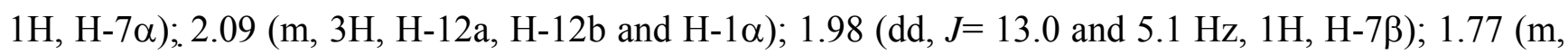




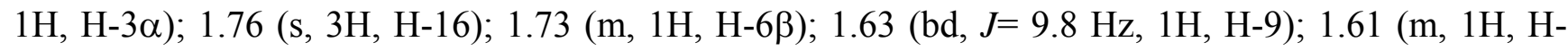
11b), 1.48 (m, 1H, H-11a); 1.31 (dd, $J=13.0$ and $4.2 \mathrm{~Hz}, 1 \mathrm{H}, \mathrm{H}-6 \alpha) ; 1.17$ (dd, $J=11.5$ and $11.5 \mathrm{~Hz}$, $1 \mathrm{H}, \mathrm{H}-3 \beta$ ); 1.08 (dd, $J=12.5$ and $2.7 \mathrm{~Hz}, 1 \mathrm{H}, \mathrm{H}-5$ ); 0.97 (dd, $J=11.5$ and $11.5 \mathrm{~Hz}, 1 \mathrm{H}, \mathrm{H}-1 \beta$ ); 0.91 (s, $3 \mathrm{H}, \mathrm{H}-18$ ); 0.86 (s, 3H, H-19); 0.73 (s, 3H, H-20). ${ }^{13} \mathrm{C}-\mathrm{NMR}: 48.0$ (C-1), 65.6 (C-2), 51.0 (C-3), 35.0 (C-4), 54.8 (C-5), 23.9 (C-6), 38.0 (C-7), 147.7 (C-8), 55.7 (C-9), 40.9 (C-10), 21.9 (C-11), 30.4 (C12), 140.3 (C-13), 124.6 (C-14), 59.0 (C-15), 23.4 (C-16), 107.3 (C-17), 33.6 (C-18), 22.6 (C-19), 15.4 (C-20). IR ( $\left.\mathrm{cm}^{-1}\right): 3,380,2,940,1,641,1,470,1,445,1,388,1,035,888,754$. M.S. (m/z, \%): $\mathrm{M}^{+} 306<$ 1\%, 291 (12.8), 288 (12.8), 273 (57.2), 270 (13.4), 257 (12.9), 255 (50.2), 245 (13.3), 207 (19.9), 205 (18.5), 203 (14.1), 202 (15.1), 199 (12.9), 190 (13.4), 189 (20.5), 188 (13.4), 187 (40.9), 175 (36.1), 173 (17.8), 163 (14.3), 150 (21.5), 149 (18.5), 148 (13.5), 147 (43.6), 145 (25.0), 137 (18.7), 136 (19.7), 135 (100.0), 134 (27.1), 133 (44.0), 131 (21.8), 123 (28.5), 122 (24.1), 121 (68.7), 120 (32.0), 119 (57.5), 117 (16.6), 111 (13.9), 109 (47.8), 108 (22.2), 107 (84.9), 106 (19.4), 105 (59.3), 97 (23.8), 96 (14.5), 95 (67.5), 94 (22.1), 93 (96.2), 92 (14.3), 91 (59.0), 85 (20.4), 84 (23.2), 83 (27.7), 81 (71.2), 80 (16.8), 79 (61.5), 77 (32.6), 71 (25.0), 69 (61.9), 68 (16.9), 67 (47.5), 57 (41.6), 55 (59.0), 53 (24.1).

Fraction II: $(0.527 \mathrm{~g}, 20.4 \%)$ viscous oil, mixture of 9-10.

Fraction III: compound 10 (1.43 g, 55.4\%) white needles, $\mathrm{mp}=104.4-106.2^{\circ} \mathrm{C}\left(\mathrm{Et}_{2} \mathrm{O} / \mathrm{MeOH}\right)$, $[\alpha]_{\mathrm{D}}{ }^{23}=-20.9^{\circ}\left(\mathrm{c} 1.05, \mathrm{CHCl}_{3}\right) ;{ }^{1} \mathrm{H}-\mathrm{NMR}: 5.38$ (bt, $\left.J=6.9 \mathrm{~Hz}, 1 \mathrm{H}, \mathrm{H}-14\right) ; 4.86$ (s, 1H, H-17b); 4.54 (s, $1 \mathrm{H}, \mathrm{H}-17 \mathrm{a}$ ); 4.15 (d, $J=6.9 \mathrm{~Hz}, 2 \mathrm{H}, \mathrm{H}-15) ; 3.88$ (ddt, $J=12.0,12.0$ and $4.4 \mathrm{~Hz}, 1 \mathrm{H}, \mathrm{H}-2$ ); 2.40 (ddd, $J=12.6,4.4$ and $2.5 \mathrm{~Hz}, 1 \mathrm{H}, \mathrm{H}-7 \alpha)$; $2.16(\mathrm{ddd}, J=12.0,9.5$ and $4.2 \mathrm{~Hz}, 1 \mathrm{H}, \mathrm{H}-12 \mathrm{~b}$ ); 2.10 (ddd, $J=$ 11.6, 4.4 and $2.5 \mathrm{~Hz}, 1 \mathrm{H}, \mathrm{H}-1 \alpha$ ); 1.97 (ddd, $J=13.9,12.6$ and $5.1 \mathrm{~Hz}, 1 \mathrm{H}, \mathrm{H}-7 \beta) ; 1.84$ (dd, $J=9.5$ and

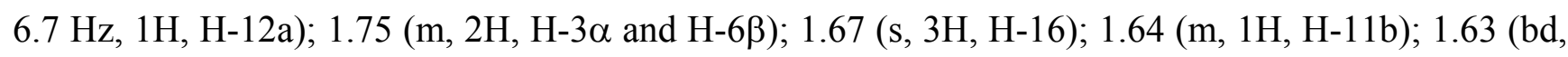
$J=10.3 \mathrm{~Hz}, 1 \mathrm{H}, \mathrm{H}-9) ; 1.49$ (m, $1 \mathrm{H}, \mathrm{H}-11 \mathrm{a}) ; 1.29$ (dd, $J=12.6$ and $4.2 \mathrm{~Hz}, 1 \mathrm{H}, \mathrm{H}-6 \alpha) ; 1.15$ (dd, $J=12.0$ and $12.0 \mathrm{~Hz}, 1 \mathrm{H}, \mathrm{H}-3 \beta) ; 1.07(\mathrm{dd}, J=12.6$ and $2.5 \mathrm{~Hz}, 1 \mathrm{H}, \mathrm{H}-5) ; 0.96(\mathrm{dd}, J=12.0$ and $12.0 \mathrm{~Hz}, 1 \mathrm{H}, \mathrm{H}-$ $1 \beta) ; 0.93$ (s, 3H, H-18); 0.84 (s, 3H, H-19); 0.72 (s, 3H, H-20). ${ }^{13} \mathrm{C}-\mathrm{NMR}: 48.2$ (C-1), 65.7 (C-2), 51.1 (C-3), 35.0 (C-4), 54.9 (C-5), 23.9 (C-6), 38.0 (C-7), 147.7 (C-8), 56.2 (C-9), 41.0 (C-10), 22.0 (C-11), 38.3 (C-12), 140.3 (C-13), 123.2 (C-14), 59.4 (C-15), 16.4 (C-16), 107.2 (C-17), 33.7 (C-18), 22.6 (C19), 15.4 (C-20). IR ( $\left.\mathrm{cm}^{-1}\right): 3,339,2,935,1646,1,464,1,440,1,388,1,363,1,030,888$. M.S. (m/z, \%): $\mathrm{M}^{+} 306$ 1.3\%, 291 (22.7), 274 (14.1), 273 (68.2), 270 (11.8), 255 (48.3), 245 (15.1), 203 (13.9), 202 (18.4), 199 (11.9), 190 (14.4), 189 (13.2), 187 (41.2), 175 (33.8), 173 (13.2), 163 (12.4), 161 (27.0), 159 (19.3), 149 (13.3), 148 (13.2), 137 (14.5), 136 (18.3), 135 (100.0), 134 (20.6), 133 (38.5), 131 (19.4), 123 (24.4), 122 (19.3), 121 (62.7), 120 (31.9), 119 (44.1), 109 (42.9), 108 (17.9), 107 (73.9), 106 (13.9), 105 (45.0), 97 (15.8), 95 (50.2), 94 (16.1), 93 (77.6), 92 (11.8), 91 (44.7), 85 (13.4), 83 (20.5), 81 (58.3), 79 (48.9), 77 (23.9), 71 (18.0), 69 (51.2), 68 (14.9), 67 (37.9), 57 (32.7), 55 (42.4), 53 (18.2).

Synthesis of 2 $\beta$-hydroxy-15-phenyl-(22,25-dihydroxy)-ent-labda-8(17), 13(E)-diene (2) from 9: To a solution of 1,4-hydroquinone $(0.086 \mathrm{~g}, 0.781 \mathrm{mmol})$ and $\mathrm{BF}_{3} \cdot \mathrm{THF}(0.2 \mathrm{~mL}, 1.59 \mathrm{mmol})$ in freshly distilled 1,4-dioxane $(5 \mathrm{~mL})$ was slowly added dropwise with stirring at room temperature and under a $\mathrm{N}_{2}$ atmosphere, a solution of $9(0.238 \mathrm{~g}, 0.777 \mathrm{mmol})$ in 1,4-dioxane $(5 \mathrm{~mL})$. After the addition was complete, stirring at room temperature and under $\mathrm{N}_{2}$ atmosphere was continued overnight. When the end of the reaction was verified by TLC, the mixture was poured onto crushed ice (app. $30 \mathrm{~g}$ ) and the 
organic layer extracted with diethyl ether $(2 \times 30 \mathrm{~mL})$, the ethereal layer was washed with $5 \%$ $\mathrm{NaHCO}_{3}(30 \mathrm{~mL})$, then with water $(2 \times 20 \mathrm{~mL})$ and dried over $\mathrm{Na}_{2} \mathrm{SO}_{4}$, filtered and evaporated. The crude was redissolved in $\mathrm{CH}_{2} \mathrm{Cl}_{2}(5 \mathrm{~mL})$ and chromatographed on silica-gel with petroleum ether/EtOAc mixtures of increasing polarity $(19.8: 0.2 \rightarrow 10.2: 9.8)$. Two main fractions were obtained: Fraction I: $0.183 \mathrm{~g}$ of non-polar unidentified complex mixture (colorless viscous oil) and Fraction II: colorless viscous oil, $40 \mathrm{mg}(13 \%)$ of compound 2.

Synthesis of 2 from 10: 1,4-hydroquinone (0.35 g, $3.18 \mathrm{mmol}), \mathrm{BF}_{3} \cdot \mathrm{THF}(0.4 \mathrm{~mL}, 3.18 \mathrm{mmol})$ and $\mathbf{1 0}$ $(0.897 \mathrm{~g}, 2.93 \mathrm{mmol})$ were used. After workup and CC purification: $0.420 \mathrm{~g}$ of complex mixture, 0.246 $\mathrm{g}(21 \%)$ of 2 and $0.172 \mathrm{~g}$ of unreacted 1,4-hydroqinone were obtained.

Synthesis of 2 from 9-10: 1,4-hydroquinone (0.093 g, $0.85 \mathrm{mmol}), \mathrm{BF}_{3} \cdot \mathrm{THF}(0.2 \mathrm{~mL}, 1.59 \mathrm{mmol})$ and 9-10 mixture $(0.258 \mathrm{~g}, 0.85 \mathrm{mmol})$ were used. After workup and $\mathrm{CC}$ purification: $0.122 \mathrm{~g}$ of complex mixture, $0.057 \mathrm{~g} \mathrm{(17 \% )}$ of diol 11 and $0.094 \mathrm{~g}(28 \%)$ of 2 were obtained.

Compound 11, colorless viscous oil, $[\alpha]_{\mathrm{D}}{ }^{23}=-48.6^{\circ}\left(\mathrm{c} 0.14, \mathrm{CHCl}_{3}\right) ;{ }^{1} \mathrm{H}-\mathrm{NMR}: 5.90$ (dd, J= 17.4 and $10.8 \mathrm{~Hz}, 1 \mathrm{H}, \mathrm{H}-14) ; 5.20$ (dd, $J=17.4$ and $1.2 \mathrm{~Hz}, 1 \mathrm{H}, \mathrm{H}-15 \mathrm{~b}) ; 5.06$ (dd, $J=10.8$ and $1.2 \mathrm{~Hz}, 1 \mathrm{H}$, $\mathrm{H}-15 \mathrm{a}) ; .4 .86$ (s, 1H, H-17b); 4.56 (s, 1H, H-17a); 3.88 (ddt, J=11.3, 11.3 and $4.4 \mathrm{~Hz}, 1 \mathrm{H}, \mathrm{H}-2$ ); 2.39. (ddd, $J=12.7,4.4$ and $2.5 \mathrm{~Hz}, 1 \mathrm{H}, \mathrm{H}-7 \alpha) ; 2.10$ (ddd, $J=11.3,4.4$ and $2.5 \mathrm{~Hz}, 1 \mathrm{H}, \mathrm{H}-1 \alpha$ ); 1.96

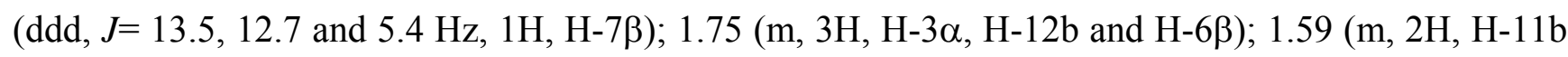
and H-9); 1.38 (m, 1H, H-11a); 1.30 (m, 1H, H-12a); 1.27 (s, 3H, H-16); 1.25 (m, 1H, H-6م); 1.43 (dd, $J=11.0$ and $11.0 \mathrm{~Hz}, 1 \mathrm{H}, \mathrm{H}-3 \beta) ; 1.07$ (dd, $J=12.5$ and $2.7 \mathrm{~Hz}, 1 \mathrm{H}, \mathrm{H}-5) ; 0.97$ (dd, $J=11.3$ and 11.3 Hz, 1H, H-1ß), 0.94 (s, 3H, H-18); 0.84 (s, 3H, H-19); 0.72 (s, 3H, H-20). ${ }^{13} \mathrm{C}-\mathrm{NMR}: 48.2$ (C-1), 65.7 (C-2), 51.1 (C-3), 35.0 (C-4), 54.9 (C-5), 23.9 (C-6), 38.1 (C-7), 147.7 (C-8), 57.1 (C-9), 41.3 (C-10), 18.0 (C-11), 41.3 (C-12), 75.3 (C-13), 145.1 (C-14), 111.7 (C-15), 27.8 (C-16), 107.4 (C-17), 33.7 (C18), 22.6 (C-19), 15.3 (C-20). IR ( $\left.\mathrm{cm}^{-1}\right): 3,375,2,935,1,445,1,368,1,035,887$. M.S. (m/z, \%): $\mathrm{M}^{+}$ $306<1 \%, 273$ (26.5), 260 (18.1), 255 (50.8), 202 (20.7), 201 (17.9), 189 (18.2), 188 (21.0), 187 (46.8), 175 (30.6), 173 (17.4), 161 (21.1), 159 (18.8), 145 (18.8), 137 (18.0), 136 (18.6), 135 (100.0), 134 (30.9), 133 (30.8), 123 (17.4), 122 (16.8), 121 (49.6), 120 (29.7), 119 (36.9), 109 (32.1), 108 (14.4), 107 (66.1), 105 (36.7), 95 (45.0), 94 (24.5), 93 (73.8), 91 (37.4), 83 (16.5), 81 (47.8), 80 (22.3), 79 (43.1), 77 (18.5), 71 (49.7), 69 (40.9), 67 (33.2), 57 (23.8), 55 (41.0).

Compound 2, colorless viscous oil, $[\alpha]_{\mathrm{D}}{ }^{23}=-18.1^{\mathrm{o}}\left(\mathrm{c} 0.38, \mathrm{CHCl}_{3}\right) ;{ }^{1} \mathrm{H}-\mathrm{NMR}: 6.67(\mathrm{~d}, \mathrm{~J}=8.6 \mathrm{~Hz}$, $1 \mathrm{H}, \mathrm{H}-23) ; 6.64$ (d, $J=2.9 \mathrm{~Hz}, 1 \mathrm{H}, \mathrm{H}-26) ; 6.57$ (dd, $J=8.6$ and $2.9 \mathrm{~Hz}, 1 \mathrm{H}, \mathrm{H}-24) ; 5.28$ (t, $J=7.1 \mathrm{~Hz}$, $1 \mathrm{H}, \mathrm{H}-14) ; 4.84$ (s, 1H, H-17b); 4.54 (s, 1H, H-17a); 3.91 (ddt, J=12.0, 12.0 and $4.2 \mathrm{~Hz}, 1 \mathrm{H}, \mathrm{H}-2$ ); 3.29 (d, $J=7.1 \mathrm{~Hz}, 2 \mathrm{H}, \mathrm{H}-15) ; 2.37$ (ddd, $J=12.0,4.7$ and $2.2 \mathrm{~Hz}, 1 \mathrm{H}, \mathrm{H}-7 \alpha) ; 2.17$ (m, 1H, H-12b); $2.10(\mathrm{~m}, 1 \mathrm{H}, \mathrm{H}-1 \alpha) ; 1.89$ (ddd, $J=15.2,12.7$ and $4.4 \mathrm{~Hz}, 1 \mathrm{H}, \mathrm{H}-7 \beta) ; 1.83$ (m, 1H, H-12a); 1.75 (m,

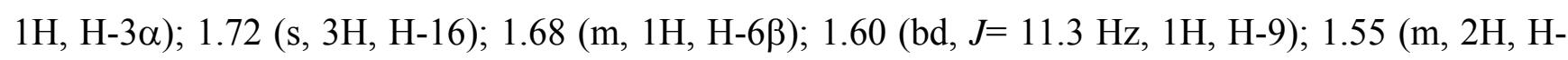
$11 \mathrm{a}$ and $\mathrm{H}-11 \mathrm{~b}$ ); 1.26 (dd, $J=11.5$ and $3.9 \mathrm{~Hz}, 1 \mathrm{H}, \mathrm{H}-6 \alpha) ; 1.17$ (dd, $J=12.0$ and $12.0 \mathrm{~Hz}, 1 \mathrm{H}, \mathrm{H}-3 \beta$ ); $0.97(\mathrm{dd}, J=12.7$ and $2.5 \mathrm{~Hz}, 1 \mathrm{H}, \mathrm{H}-5) ; 0.94$ (dd, $J=12.0$ and $12.0 \mathrm{~Hz}, 1 \mathrm{H}, \mathrm{H}-1 \beta) ; 0.91$ (s, 3H, H-18); 0.82 (s, 3H, H-19); 0.69 (s, 3H, H-20). ${ }^{13} \mathrm{C}-\mathrm{NMR}: 47.9$ (C-1), 66.1 (C-2), 50.7 (C-3), 35.0 (C-4), 54.6 (C-5), 23.8 (C-6), 38.0 (C-7), 147.6 (C-8), 55.3 (C-9), 40.8 (C-10), 22.0 (C-11), 37.7 (C-12), 138.1 (C13), 121.7 (C-14), 29.0 (C-15), 16.8 (C-16), 107.2 (C-17), 33.6 (C-18), 22.6 (C-19), 15.3 (C-20), 128.7 (C-21), 147.7 (C-22), 116.3 (C-23), 113.7 (C-24), 149.5 (C-25), 116.6 (C-26). IR ( $\left.\mathrm{cm}^{-1}\right)$ : 3,375, 2,935, 
1,455, 1,199, 1,025. M.S. (m/z, \%): $\mathrm{M}^{+} 398<1 \%, 280$ (2.6), 279 (14.5), 168 (3.3), 167 (36.4), 149 (100.0), 113 (8.4), 112 (5.3), 104 (5.5), 84 (2.8), 83 (5.1), 76 (2.7), 71 (13.8), 70 (12.2), 69 (33.0), 57 (17.8), $55(7.0)$.

\section{Acknowledgements}

The authors thank the Dirección de Investigación y Postgrado (DGIP) of the Universidad Técnica Federico Santa María (grant $\mathrm{N}^{\circ}$ 13.08.59, 13.09.42 and PIIC QUI 2009) and Universidad de Valparaiso (grant DIPUV 21/2005 and 27/2006) for financial support, to Miss Marcia Manríquez for important technical assistance.

\section{References and Notes}

1. Capon, R.J. Studies in Natural Products Chemistry. Structure and Chemistry, Part C; ur-Rahman, A., Ed.; Elsevier: Amsterdam, The Netherlands, 1995; Vol. 15, pp. 289-326.

2. De Rosa, S.; de Giulio, A.; Iodice, C. Biological Effects of Prenylated Hydroquinones: StructureActivity Relationship Studies in Antimicrobial, Brine Shrimp, and Fish Lethality Assays. J. Nat. Prod. 1994, 57, 1711-1716.

3. Müller, W.E.G.; Maidhof, A.; Zahn, R.K.; Schröder, H.C.; Gasiae, M. J.; Heidemann, D.; Bernd, A.; Kurelec, B.; Eich, E.; Seibert, G. Potent Antileukemic Activity of the Novel Cytostatic Agent Avarone and Its Analogues in Vitro and in Vivo. Cancer Res. 1985, 45, 4822-4826.

4. Chen, C.Y.; Shen, Y.C.; Chen, Y.J.; Sheu, J.H.; Duh, C.Y. Bioactive Sesquiterpenes from A Taiwanese Marine Sponge Parahigginsia sp. J. Nat. Prod. 1999, 62, 573-576.

5. Shen, Y.C.; Hsieh, P.W. New Sesquiterpene Hydroquinones from a Taiwanese Marine Sponge Polyfibrospongia australis. J. Nat. Prod. 1997, 60, 93-97.

6. Talpir, R.; Rudi, A.; Kashman, Y. Three new Sesquiterpene Hydroquinones from Marine Origin. Tetrahedron 1994, 50, 4179-4184.

7. Prokofeva, N.G.; Utkina, N.K.; Chaikina, E.L.; Makarchenko, A.E. Biological Activities of Marine Sesquiterpenoid Quinones: Structure-Activity Relationships in Cytotoxic and Hemolytic Assays. Comp. Biochem. Physiol. Part B 2004, 139, 169-173.

8. Hamann, M.T.; Scheuer, P.J.; Kelly-Borges, K. Biogenetically Diverse, Bioactive Constituents of a Sponge, Order Verongida: Bromotyramines and Sesquiterpene-Shikimate Derived Metabolites J. Org. Chem. 1993, 58, 6565-6569.

9. Alvi, K.; Diaz, M.C.; Crews, P. Slate, D.L.; Lee, R.H.; Moretti, R. Evaluation of New Sesquiterpene Quinones from two Dysidea Sponge Species as Inhibitors of Protein Tyrosine Kinase. J. Org. Chem. 1992, 57, 6604-6607.

10. Schröder, H.C.; Sari, P.S.; Rottmann, M.; Wenger, R.; Maidhof, A.; Renneisen, K.; Müller, W.E.G. Differential Modulation of Host Cell and HIV Gene Expression by Combinations of Avarol and AZT in vitro. Biochem. Pharmacol. 1988, 37, 3947-3952.

11. Schröder, H.C.; Wenger, R.; Gerner, H.; Reuter, P.; Kuchino, Y.; Sladiae, D.; Müller, W.E.G. Suppression of the Modulatory Effects of the Antileukemic and Anti-Human Immunodeficiency Virus Compound Avarol on Gene Expression by Tryptophan. Cancer Res. 1989, 49, 2069-2076. 
12. Loya, S.; Tal, R.; Kashman, Y.; Hizi, A. Illimaquinone, a Selective Inhibitor of the RNase H Activity of Human Immunodeficiency Virus Type 1 Reverse Transcriptase. Antimicrob. Agents Chemother. 1990, 34, 2009-2012.

13. Barrero, A.F.; Alvarez-Manzaneda, E.J.; Chahboun, R. Enantiospecific Synthesis of (+)Puupehenone from (-)-sclareol and Protocatechualdehyde. Tetrahedron Lett. 1997, 38, 23252328.

14. Seifert, K., Schröder, J., Matthes, B., Total Synthesis of the Marine Sesquiterpene Quinone (-)cyclozonarone. Tetrahedron Lett. 2001, 42, 8151-8152.

15. Cortés, M.; Valderrama, J.A.; Cuellar, M.; Armstrong, V.; Preite, M.; Synthesis of (+)Cyclozonarone and the Absolute Configuration of Naturally Occurring (-)-Cyclozonarone. J. Nat. Prod. 2001, 64, 348-349.

16. Poigny, S.; Guyot, M.; Samadi, M.; Efficient Total Synthesis of (-)-Ilimaquinone. J. Org. Chem. 1998, 63, 5890-5894.

17. Laube, T.; Beil, W.; Seifert, K. Total Synthesis of two 12-nordrimanes and the Pharmacological Active Sesquiterpene Hydroquinone Yahazunol. Tetrahedron 2005, 61, 1141-1148.

18. Almeida, W.P.; Correira, C.R.D. Stereoselective Total Synthesis and Enantioselective Formal Synthesis of the Antineoplastic Sesquiterpene Quinone Metachromin A. J. Braz. Chem. Soc. 1999, 10, 401-414.

19. González, A.G.; Martín, J.D. Thes Synthesis of a Taondiol Derivative. Tetrahedron Lett. 1972, 22, 2259-2260.

20. González, A.G.; Darias, J.; Martín, J.D.; Pascual, C. Marine Natural Products of the Atlantic Zone-V. The Structure and Chemistry of Taondiol and Related Compounds. Tetrahedron 1973, 29, 1605-1609.

21. Espinonza, L.; Carrasco, H.; Cuellar, M.; Gallardo, C.; Catalán, K. Oxidative Degradations of the Side Chain of Unsaturated Ent-labdanes. Part I. Molecules 2007, 12, 318-327.

22. Bastard, J.; Duc-Khac, D.; Fetizon, M. CMR Spectroscopy of Labdanic Diterpenes and Related Substances. J. Nat. Prod. 1984, 47, 592-599.

23. Forster, P.G.; Ghisalberti, E.L.; Jefferies, P.R. Labdane Diterpenes from an Acacia Species. Photochemistry 1985, 24, 2991-2993.

Sample Availability: Samples of compounds 1-2 are available from the authors.

(C) 2009 by the authors; licensee Molecular Diversity Preservation International, Basel, Switzerland. This article is an open-access article distributed under the terms and conditions of the Creative Commons Attribution license (http://creativecommons.org/licenses/by/3.0/). 